\title{
Die Moeder-Kind Verhouding
}

\author{
M. de J. Potgieter (M. Med. (Paed.)
}

\section{SUMMARY}

\author{
Most parents with "problem children" have other children who present few or no problems, but they \\ declare, practically without exception, that from the start they have been unable to fathom their "problem \\ child". \\ Early help in this connection could be valuable. \\ A mother will appreciate recognition of her baby as an individual by a doctor or nurse and will be readier to \\ approach them later with her problems.
}

${ }^{6} \mathrm{M}$ OEDER" word in my woordeboek definieer as: 'n Vrou wat 'n kind gebaar of aangeneem het en " $n$ moeder se kenmerke is om lief te hê, te beskerm, op te pas en te voed.

,Kind"': enige persoon tussen geboorte en puberteit. Streng gesproke is hierdie definisie korrek aangesien die ongebore kind nog ' $\mathrm{n}$ fetus is. Dit is egter nie waar dat die verandering wanneer die naelstring geknip word so absoluut is nie. Die baba het reeds vir 40 weke ontwikkel en meer gewaarwordinge ondervind as wat ons tot dusver van bewus was. So is dit dan bewys dat die ongebore baba reeds kan reageer op klank (verandering van fetale hartspoed) en is dit ook gevind dat wanneer die pasgebore baba na geboorte blootgestel word aan 'n manlike stem aan die eenkant en 'n vroulike stem aan die anderkant — hy sy kop betekenisvol meer in die rigting van die vroulike stem sal draai, omdat hy reeds intrauterien gewoond geraak het aan ma se stem.

Dit is verder bewys dat moeders wat angstig was gedurende swangerskap, se babas neonataal meer huil, en waar die moeder ernstige emosionele spanning ondervind het is die babas se geboortemassa minder en is hulle geneig om meer aktief te wees. "n Indruk van konstitusionele of temperamentele eienskappe, mag dus reeds voor geboorte gekry kan word - bv. die baba se sikliese patroon van wakker wees en slaap. Die moeder ervaar en leer dus die baba tot 'n mate ken volgens die manier wat hy binne haar beweeg. Daar is ook gevind dat piloriese stenose meer voorkom by die babas van moeders wat gedurende die laaste trimester van swangerskap deur spanningsituasies gegaan het.

Wanneer die baba in die kraaminrigting is, is dit reeds baie belangrik om hom goed dop te hou, sy aktiwiteit en sikliese patroon op te merk en hiervolgens aan die moeders vooruit 'n idee te gee omtrent sy hantering tuis. 'n Moeder sal dit verder ook waardeer dat die verpleegster of dokter haar baba raaksien as ' $n$ persoon op sy eie en meer geneig wees om later met haar probleme na hulle te gaan. Deur kennis omtrent wat sy te wagte kan wees, kan sy ook met meer objektiwiteıt teenoor die baba optree. Meeste ouers met "probleemkinders" het ander kinders wat geen of min probleme gee, maar hulle meld feitlik sonder uitsondering dat hulle die betrokke kind van die begin af nooit kon peil nie. Vroeë hulp in verband hiermee kan probleme voorkom. Resultate met metodes wat tot dusver gevolg is, het egter nie 'n betekenisvolle verskil aan die kind se latere gedrag gemaak nie. Beter metodes om die moeder voor te berei om verwagte gedrag by haar kind te hanteer en voorkomend op te tree moet nog gevind word. In die verband moet ook gewaak word om nie nadelige verwagtinge te koester wat dan wel tot vervulling kan kom nie.

Leboyer se metode om die baba na geboorte te hanteer ontvang ook nou baie aandag. Die kind moet in 'n rustige atmosfeer sy eerste lewenslig (nie te skerp nie) sien, met ferm hande hanteer word (sekuriteit) met lekker lou warm water afgespoel word en deur die moeder teen haar naakte bors gehou word. Dit mag bietjie vergesog klink, maar dit kan tog verstaan word hoeveel warmte en sekuriteit en aan die ander kant liefde en die vervulling van moederskapsdrang tussen die baba en sy ma op hierdie tydstip ondervind word. Dit word ook voorgestel dat selfs al word die baba kunsgevoed, die moeder hom in elk geval, waar moontlik, gedurende die voedingstyd teen haar bors moet hou.

Daar verskyn ook teenswoordig heelwat artikels omtrent die invloed van vroeë fisiese kontak tussen moeder en baba wat dan die verdere verhouding tussen hulle beinvloed. Kennel $e t$ al meen daar is aanduidings van 'n sensitiewe periode (moontlik gedurende die eerste uur of in elk geval binne die eerste 12 uur waar kontak tussen ma en baba uiters belangrik is vir hulle verhouding ("bonding"). Die kind se toestand binne 'n uur na 'n normale bevalling is dan ook dat hy goed wakker is en geneig om te wil suig. Daar is studies wat aantoon dat moeders wat vroeg begin borsvoed langer daarmee aanhou. Vroeë borsvoeding skyn egter nie so belangrik te wees vir die sukses van borsvoeding as dat die ma en kind bymekaar moet wees, die voeding op aanvraag moet wees en ondersteuning van die personeel gegee moet word.

Die verhouding tussen die kind en sy moeder en ná haar ook die vader word hopelik dieper en inniger soos wat sy persoonlikheid ontwikkel. Sosio-ekonomiese faktore mag sorg en sekuriteit belemmer, maar nie altyd emstige gevolge 
hê nie. Die ouers moet gedurig trag om aan die kind aanvaarding (liefde) en sekuriteit (nie net materieel nie) te bied. Verder moet daar positiewe en tot 'n mindere mate ook negatiewe interaksie tussen die ouers en kind bestaan (die stel van eise). Aan die basiese drange van die kind nl. nuuskierigheid, kameraadskap en eie waarde moet kans gegee word om binne perke tot uiting te kom. Slegs indien die moeder sekuriteit in haarself besit kan sy waarlik sekuriteit aan haar kind gee. Ouers wat afhanklik is van hulle kind se goedkeuring van hulle optrede ondervind later baie probleme met die kind se opvoeding.

Die moeder- (vader) kinderverhouding ontwikkel nou verder en verskil in sekere opsigte afhangend of dit ' $n$ seuntjie of ' $n$ dogtertjie is.

Vanaf geboorte tot 3 of 4 maande ouderdom onderskei die kind nie sy ma onathanklik van homself nie. Dit is die sogenaamde outistiese stadium en die kind se gewaarwordinge draai net om homself. Deur die moeder se optrede behoort sy reeds die kind op hierdie stadium te vul met haar lewenslus.

Vanaf 3 tot 4 maande word die kind bewus dat daar 'n persoon behalwe homself is met wie hy eintlik 'n simbiotiese verhouding het - sy ma. Hy raak om en by 8 maande angstig as hy van sy moeder geskei word. Hierdie fase word afgerond op ongeveer 12 tot 18 maande.

Hierna volg die sogenaamde "toddler" stadium (12 - 36 maande). Gedurende hierdie tydperk word die kind se gevoel van mag (almag) getemper deur die eise wat die ouers aan hom stel. Hy ontwikkel ook die vermoë om afhanklikheid te verstaan. Aggressiewe drange is nou in stryd met afhanklikheidsgevoel, liefde en behoefte aan goedkeuring. Hy raak baie ambivalent en ook negativisties. Ouers se idealisering van hulle kind word taamlik versteur deur hierdie optrede. Hy raak meer bewus van ander persone en hy ontwikkel voorkeur/verhoudings en wisselinge in die intensiteit daarvan.
Hierna tot ongeveer 6 jaar is die voorskoolse stadium waarin die sogenaamde oedipus konflik voorkom. Die seun sien sy vader as mededinger van sy moeder se liefde en so die dogter teenoor haar moeder. Later ontwikkel (of behoort hulle) slegs 'n gevoel van tederheid teenoor die ouer van die teenoorgestelde geslag en identifiseer die kind met die ouer van dieselfde geslag.

Gedurende die volgende periode van 8 tot 10 jaar is die kind in die latente stadium of middelkinderjare. Hy vorder met die verhoudings wat reeds bereik is en addisionele identifikasie onstaan - bv. met 'n onderwyser, wat natuurlik ook kritiek teenoor die ouers se manier van optrede kan uitlok. Groepe van dieselfde geslag word ook gevorm.

Daarna kom puberteit en adolessensie. Kinders beweeg nou duidelik weg van hulle ouers en kan krities en opstandig raak. Hulle identifiseer dikwels beter met volwassenes jonger as hulle eie ouers - goed of sleg - en soek veral die geselskap van ander adolessente op. Wanneer die kind egter sy biologiese en kulturele uitdagings oorkom het, beweeg hy weer nader aan die ouers en word ook hopelik geleidelik ' $n$ volwasse lid van die gemeenskap.

\footnotetext{
BRONNELYS

Brazelton, T.B et al. (1976): Current problems in Pediatrics, VII, No. 2

2. Reville, S.I., Dodge, J.A. (1978): Archives of Diseases in Childhoof, 53:66

3. Mclnemy, T., Chamberlain, R.W. (1978): Clinical Pediatrics, 17:234.

4. Leboyer, F. (1977): Birth without violence, Fontana Publishers.

5. Johnson, N.W : Breast-feeding at one hour of age, MCN: 1976: Am J Mater Child Nurs., 1:12.

6. Raphael, D: The lactation-suckling process with a matrix of supportive behaviour. (1966): Ann Arbor, University Microfilms.

7. Stone, F.H. (1976): Psychiatry and the Paediatrician (Postgraduate Paediatric Series) London: Butterworths.

8. Nelson, (1975): Textbook of Paediatrics. Philadelphia: W.B. Saunders
} 